\title{
GNREL \\ Spring 2012 Composite Data Products - Backup Power
}

\section{J. Kurtz, K. Wipke, S. Sprik, T. Ramsden, C. Ainscough, G. Saur}

\section{April 3, 2012}

\author{
NREL/PR-5600-55311
}




\section{Backup Power Fuel Cell Systems Deployed}

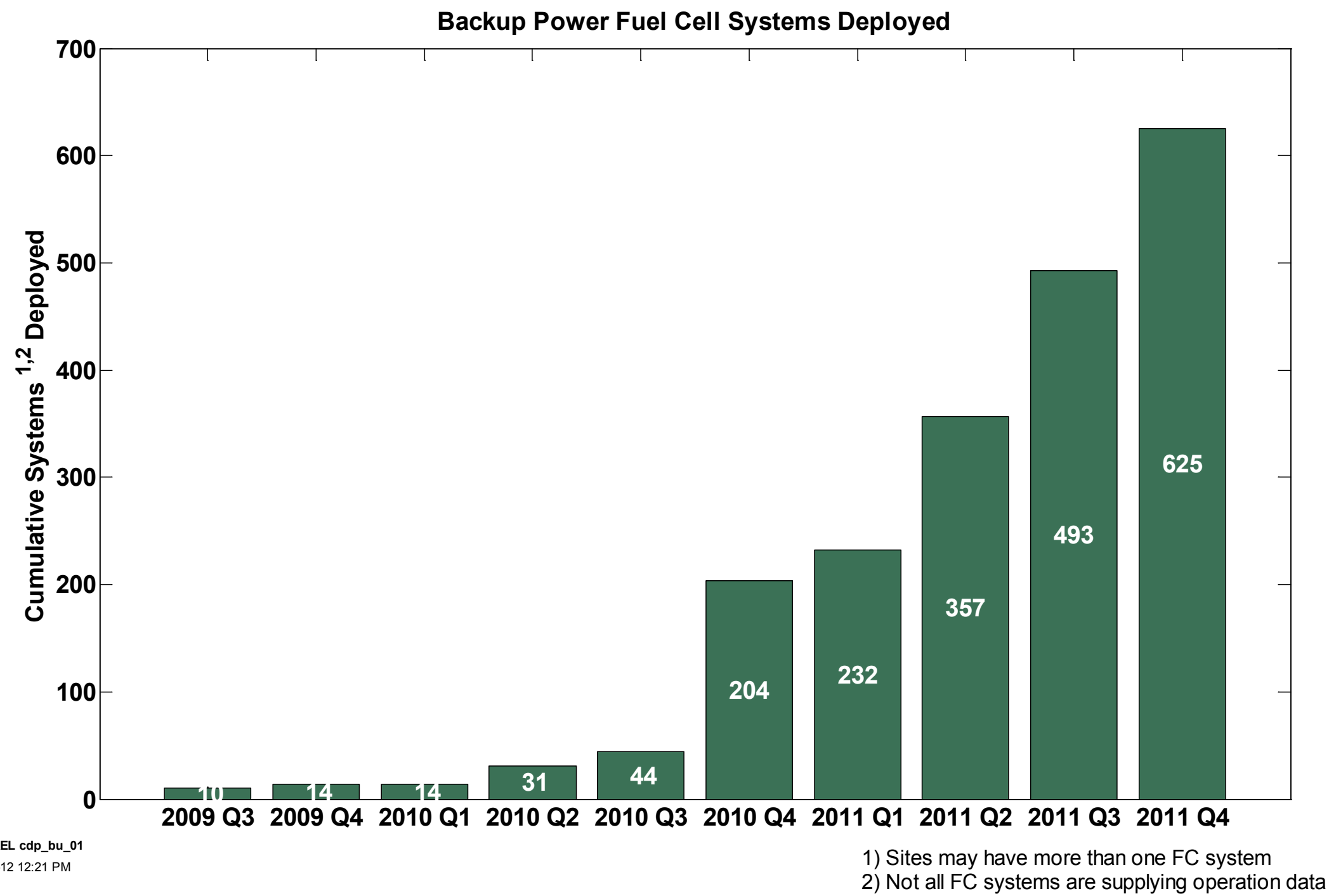




\section{Deployed kW Capacity for Backup Power}

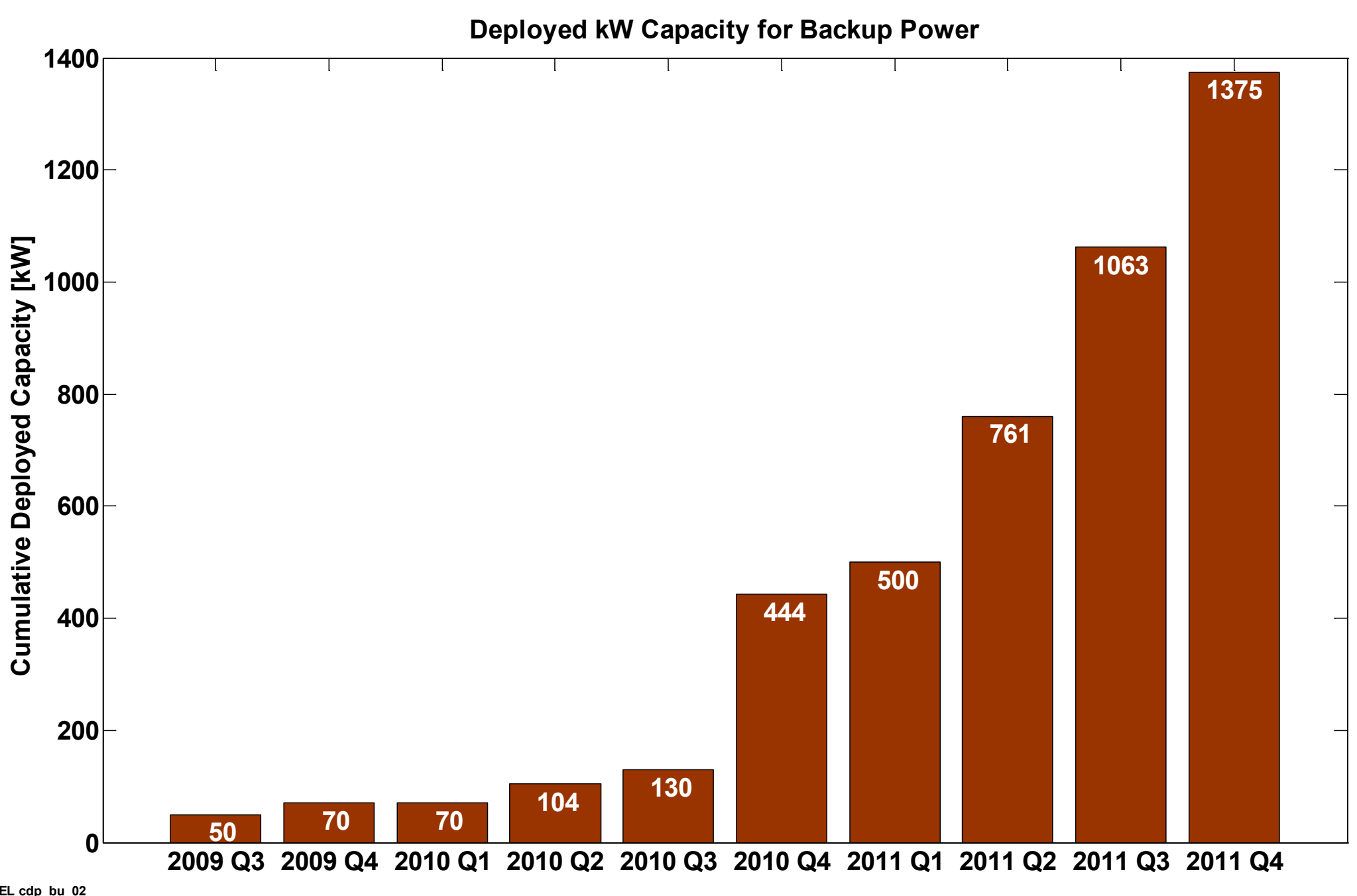

J NREL cdp bu 02 Created: Mar-26-12 12:22 PM 


\section{Backup Power Deployments}

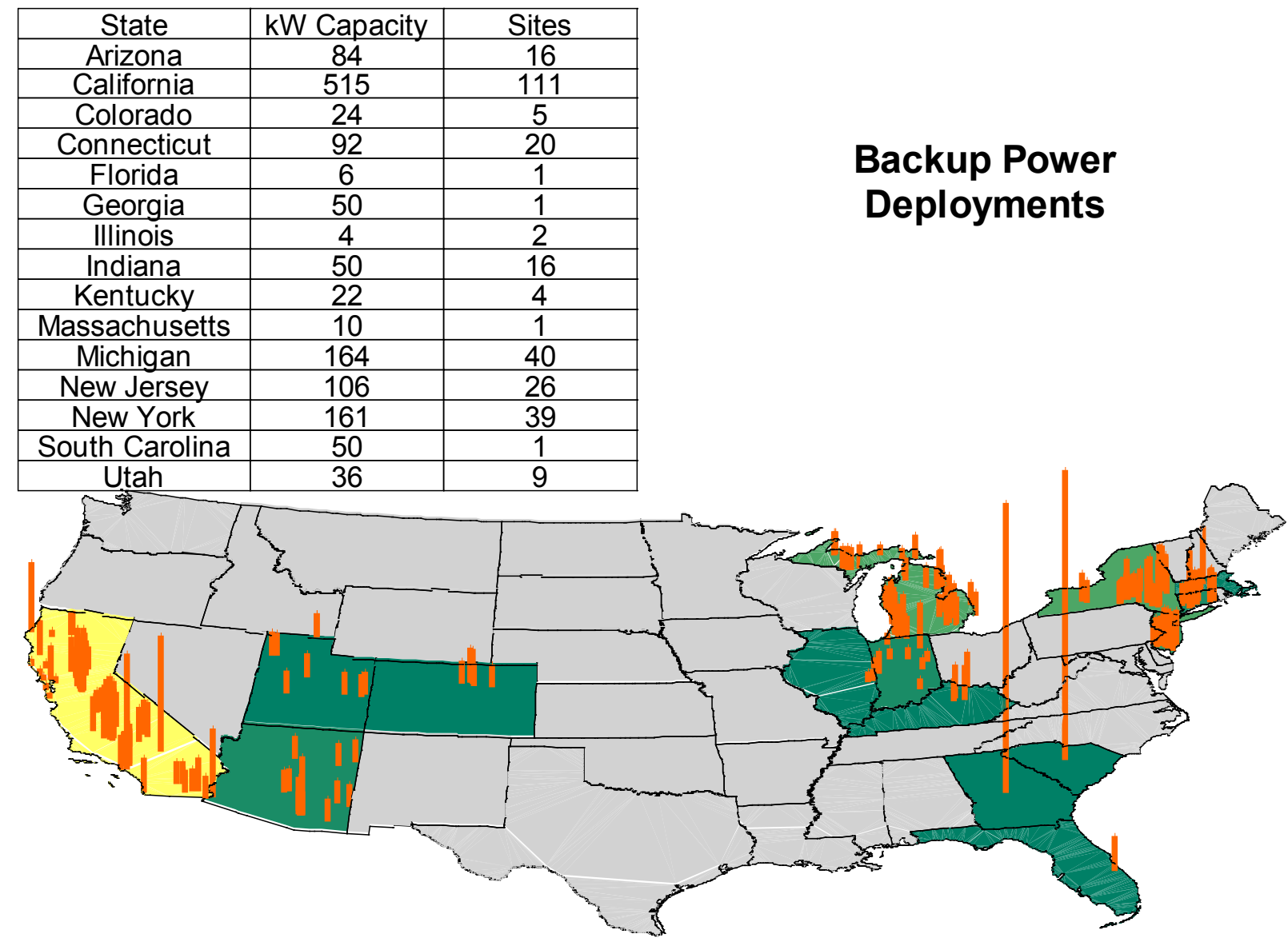

Totals

Site Capacity (line height proporational to installed site kW capacity)

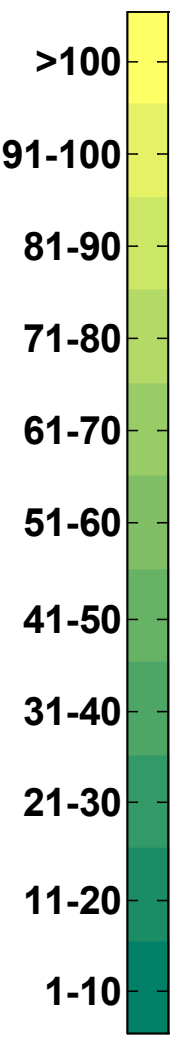

Number of Sites in State 


\section{Starts by Month}

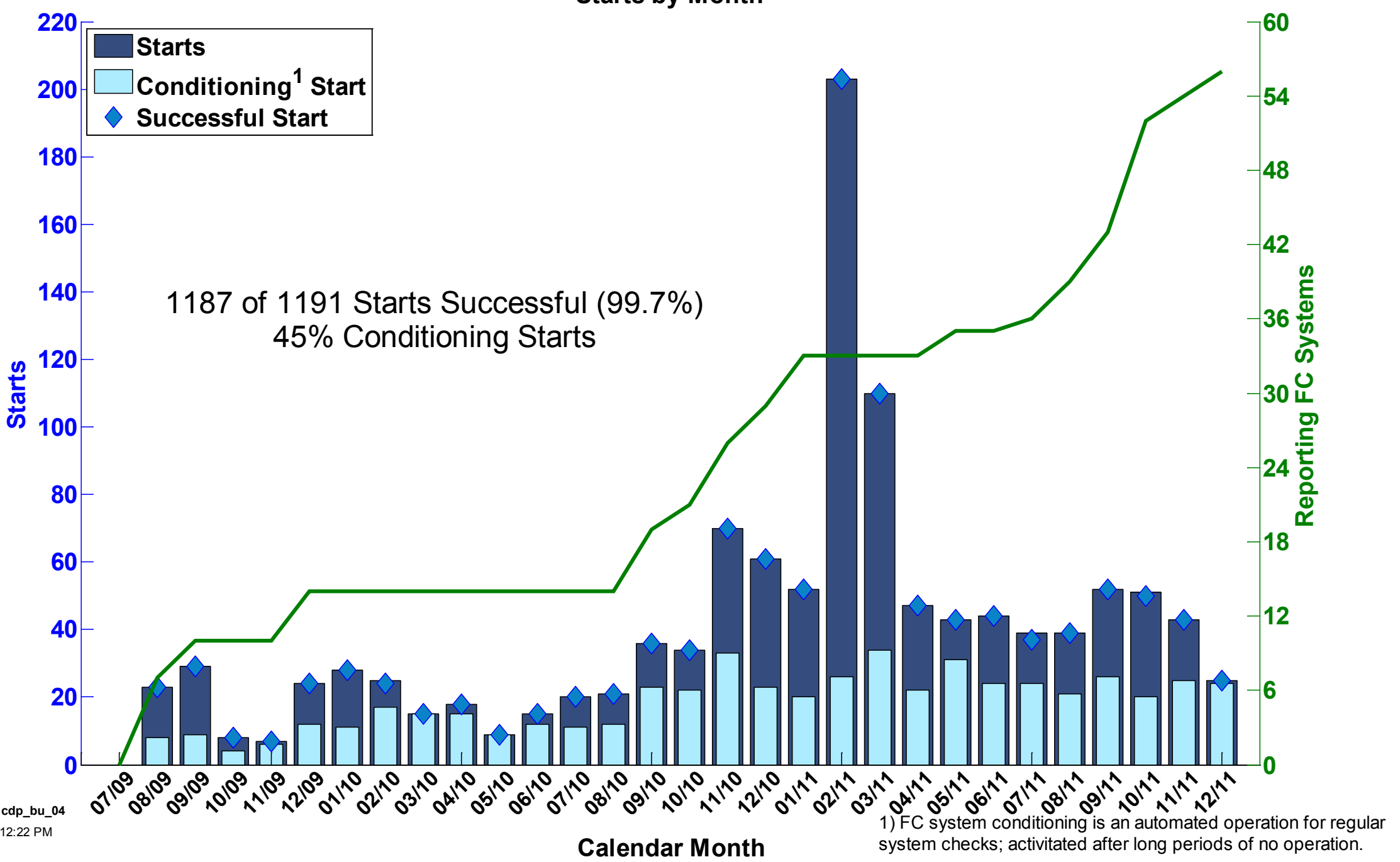




\section{Fuel Cell System Run Hours by Month}

\section{Run Hours by Month}

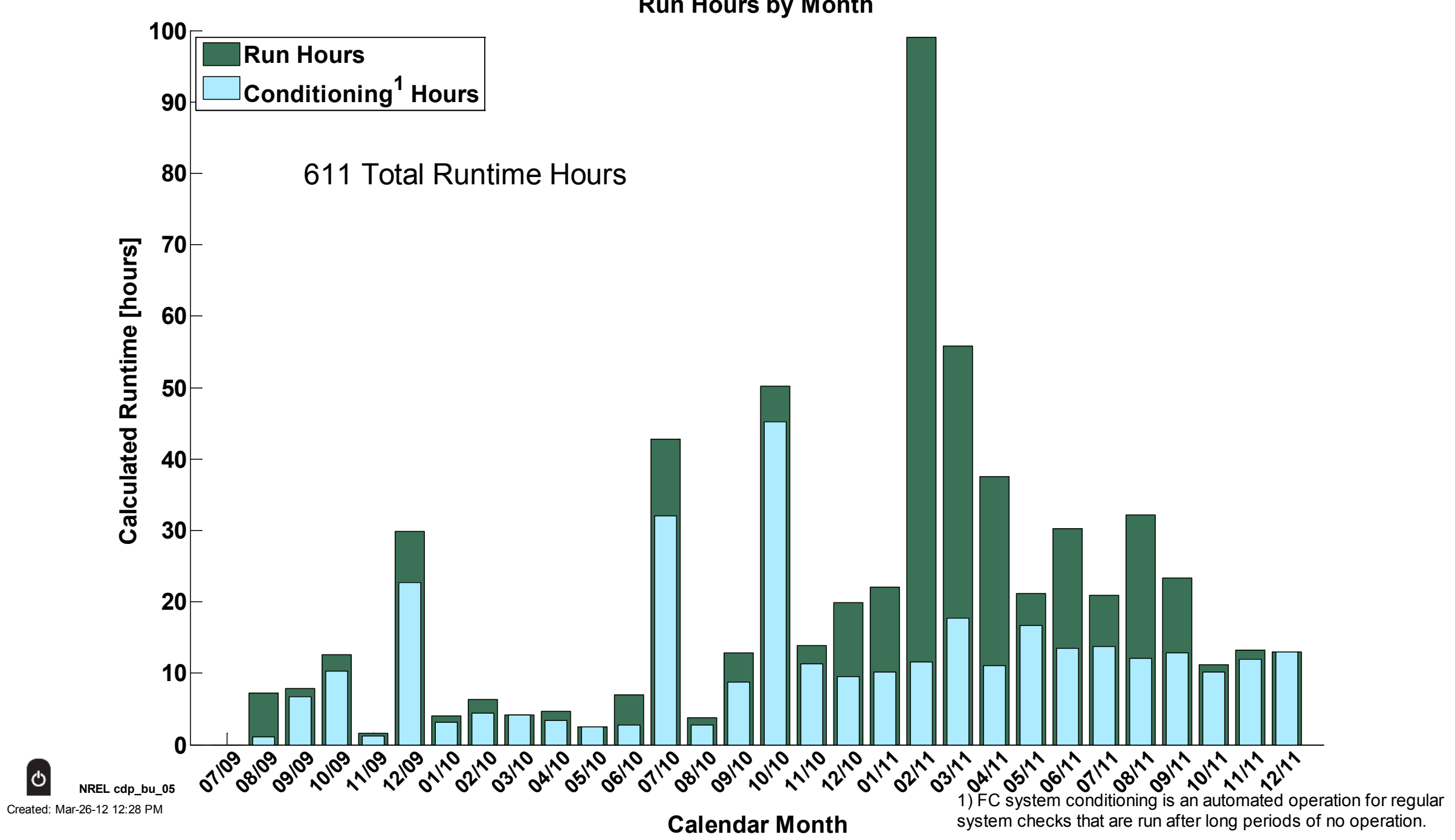


CDP-BU-06

Cumulative Hydrogen Consumed by Month

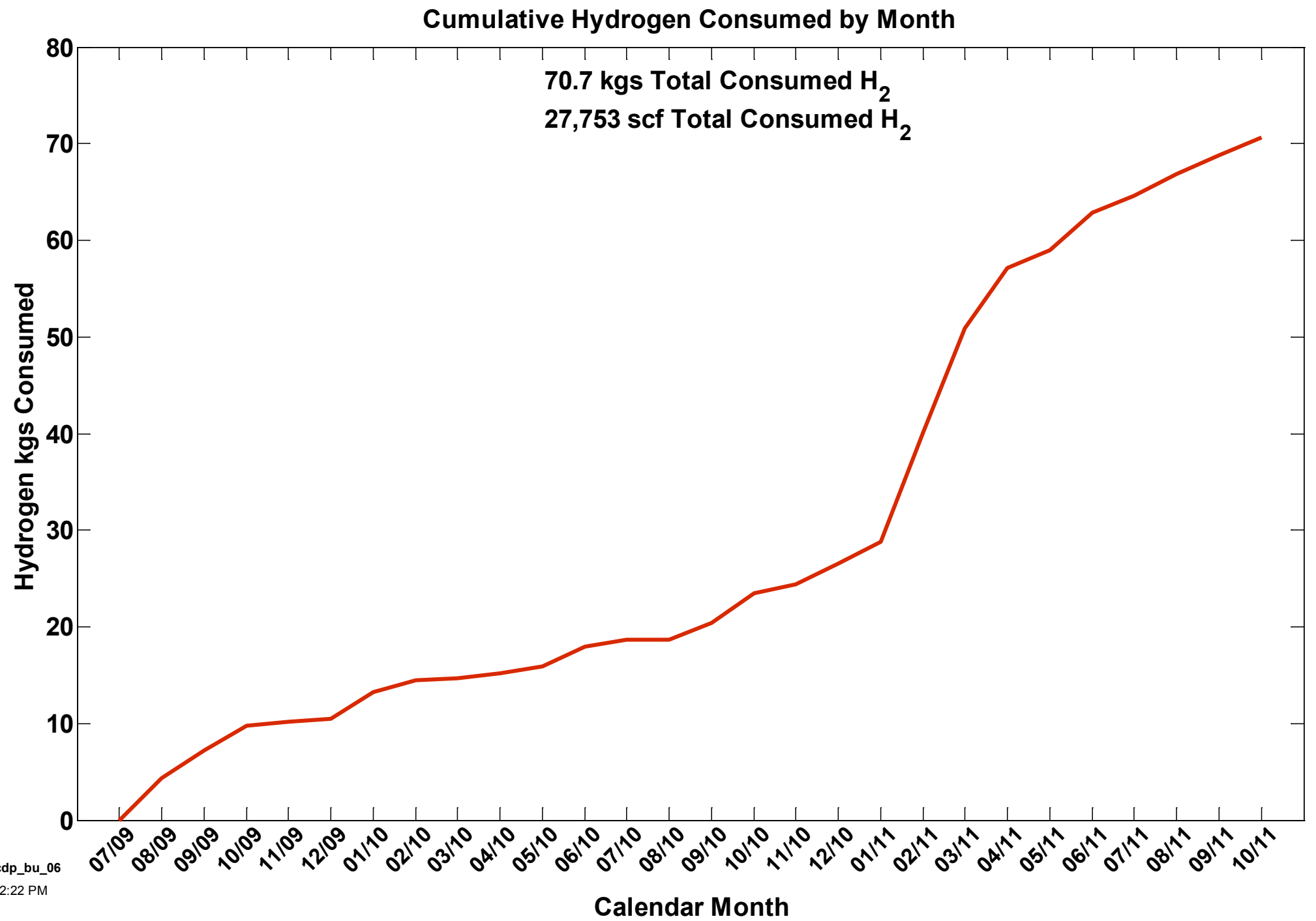

NATIONAL RENEWABLE ENERGY LABORATORY

7 


\section{Fuel Cell System Starts by Day of Week}

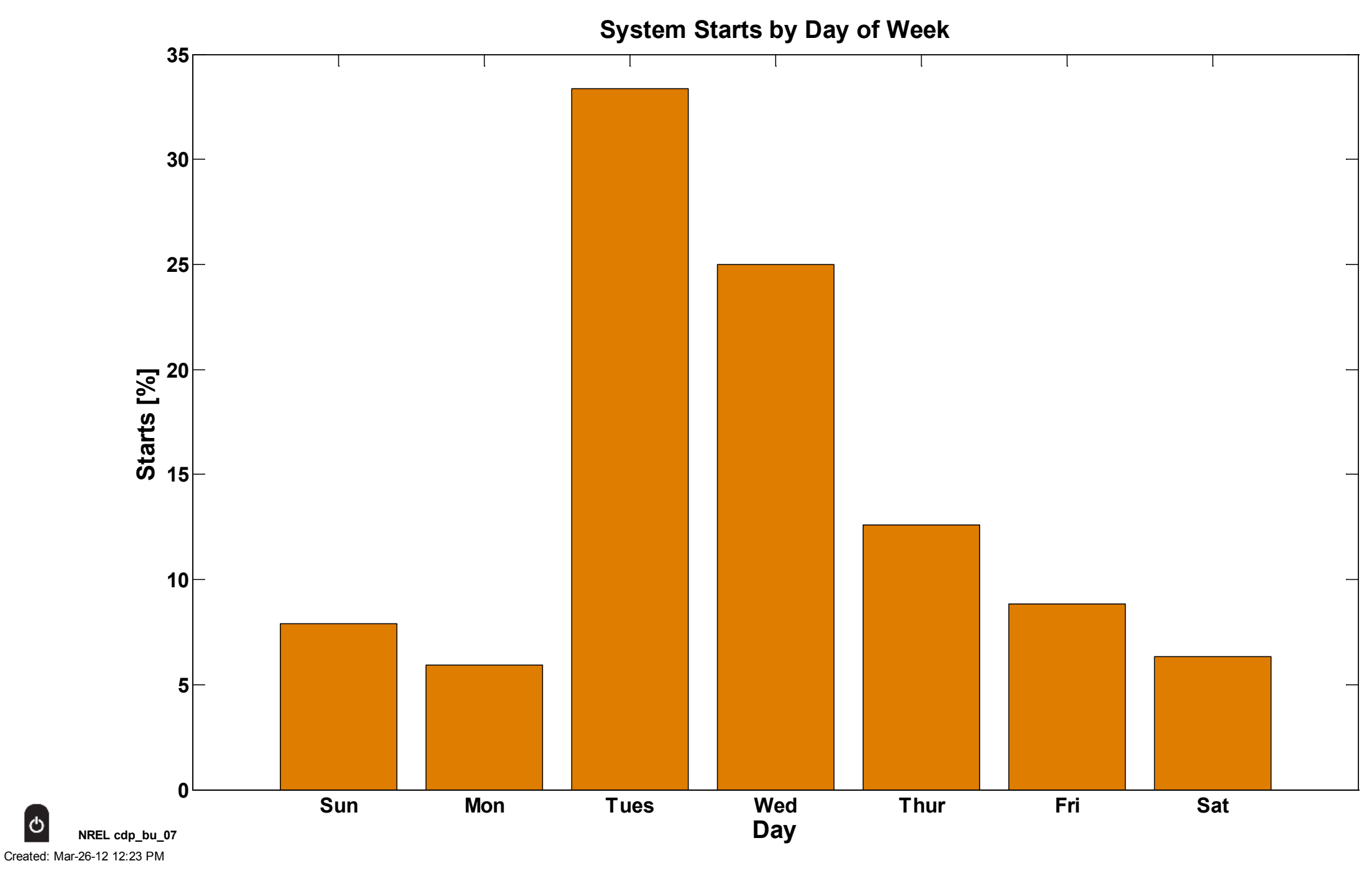




\section{Fuel Cell System Starts by Time of Day}

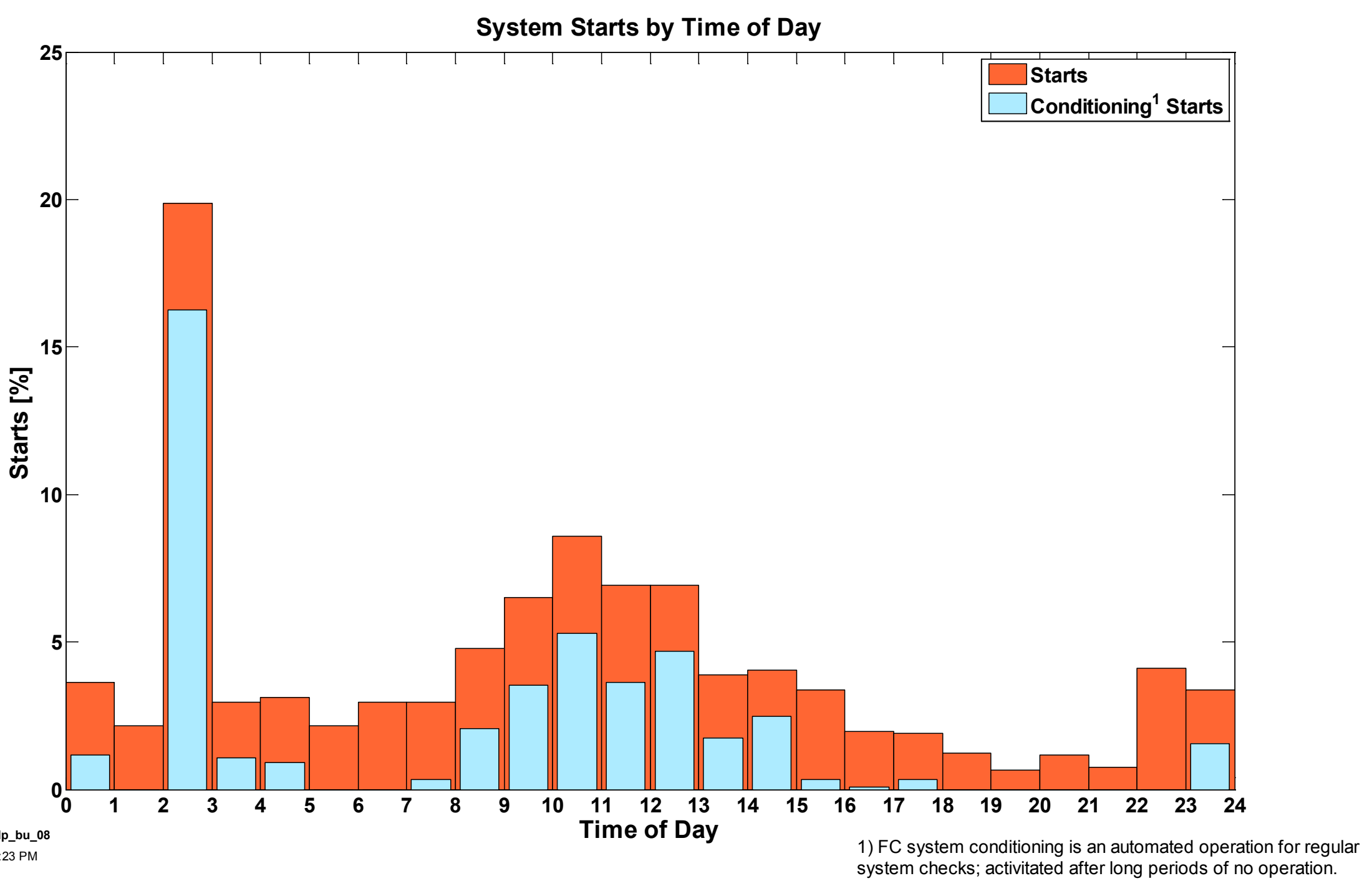




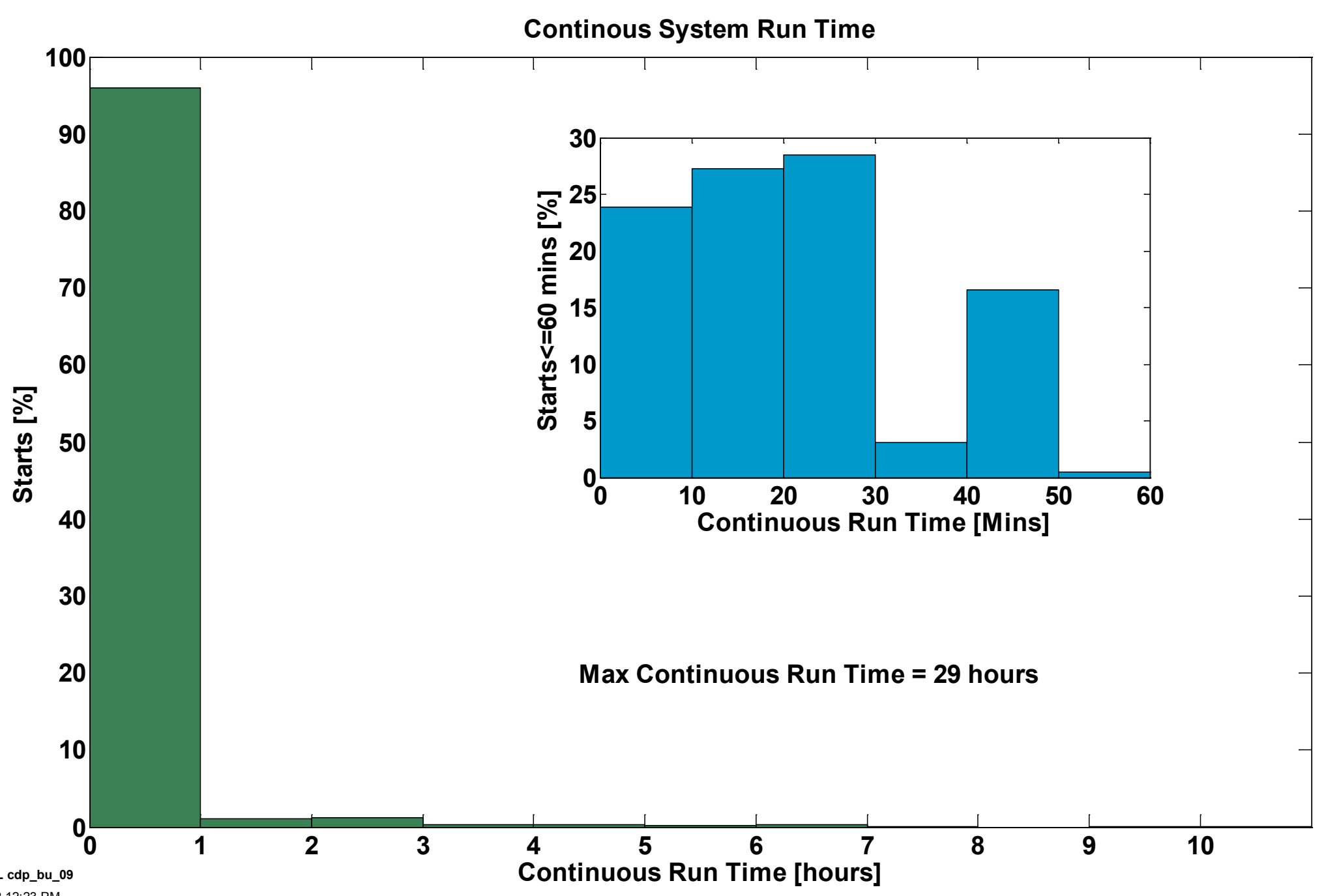




\section{Unsuccessful Operation Categories}

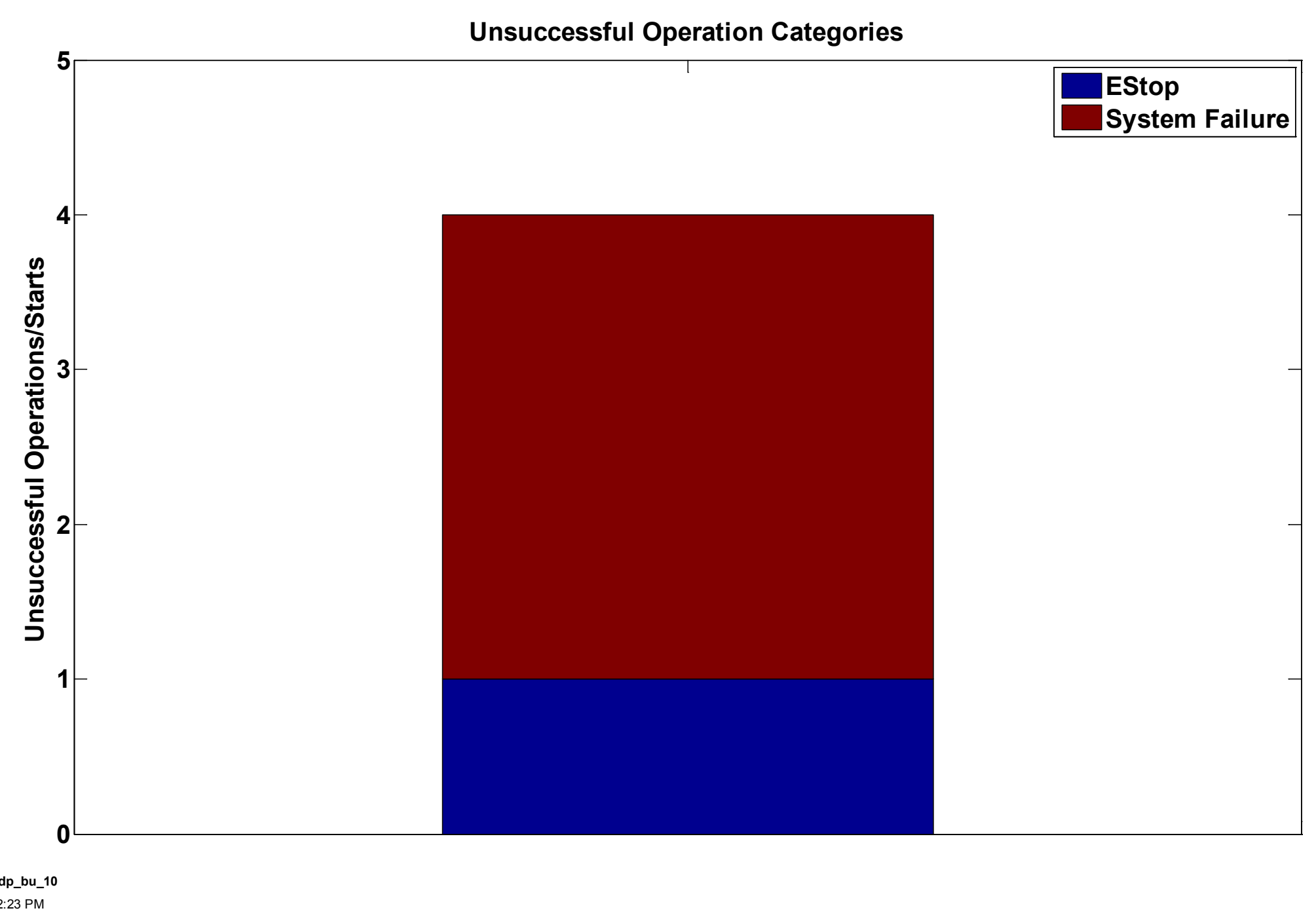




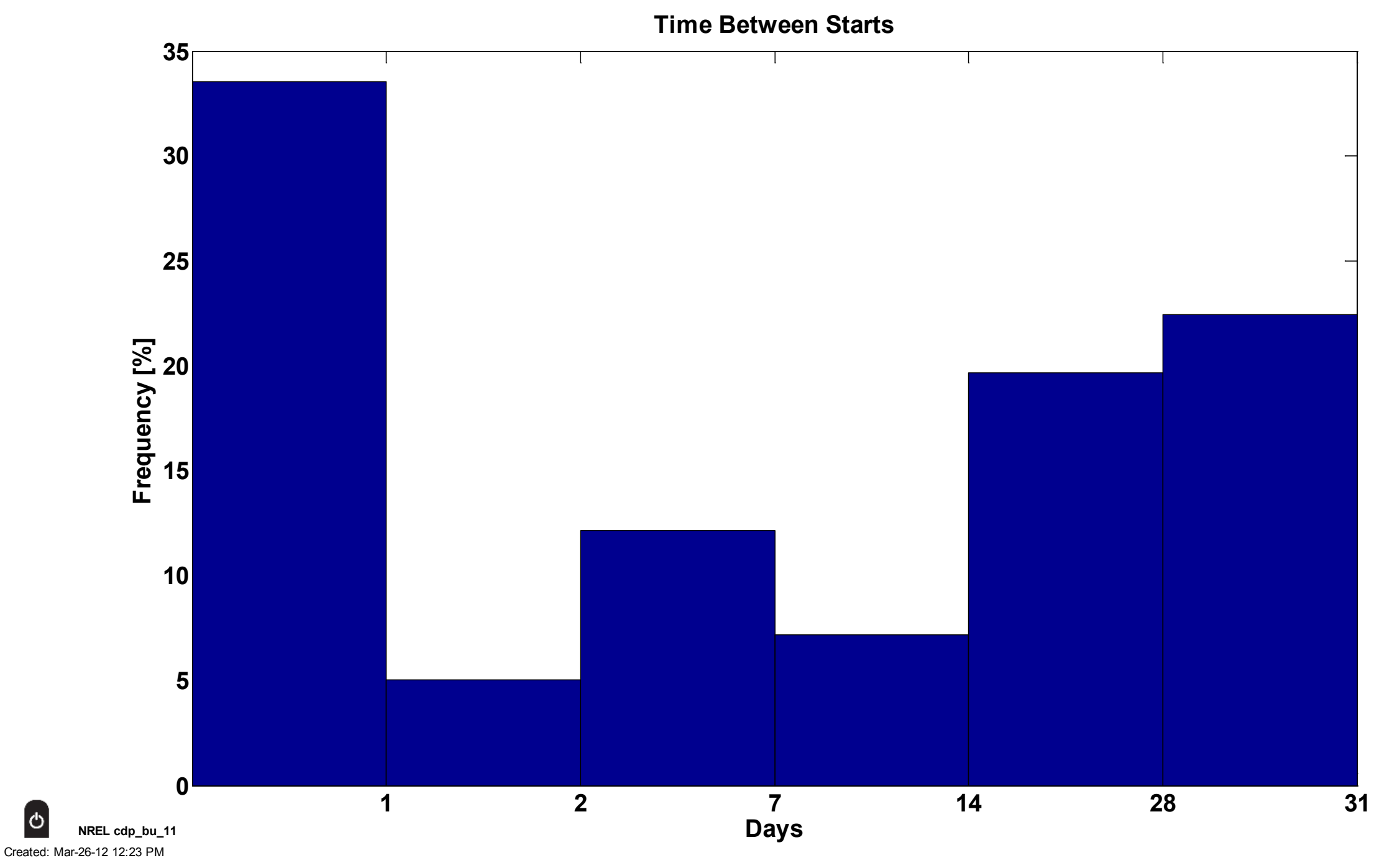




\section{System Start Ambient Temperature}

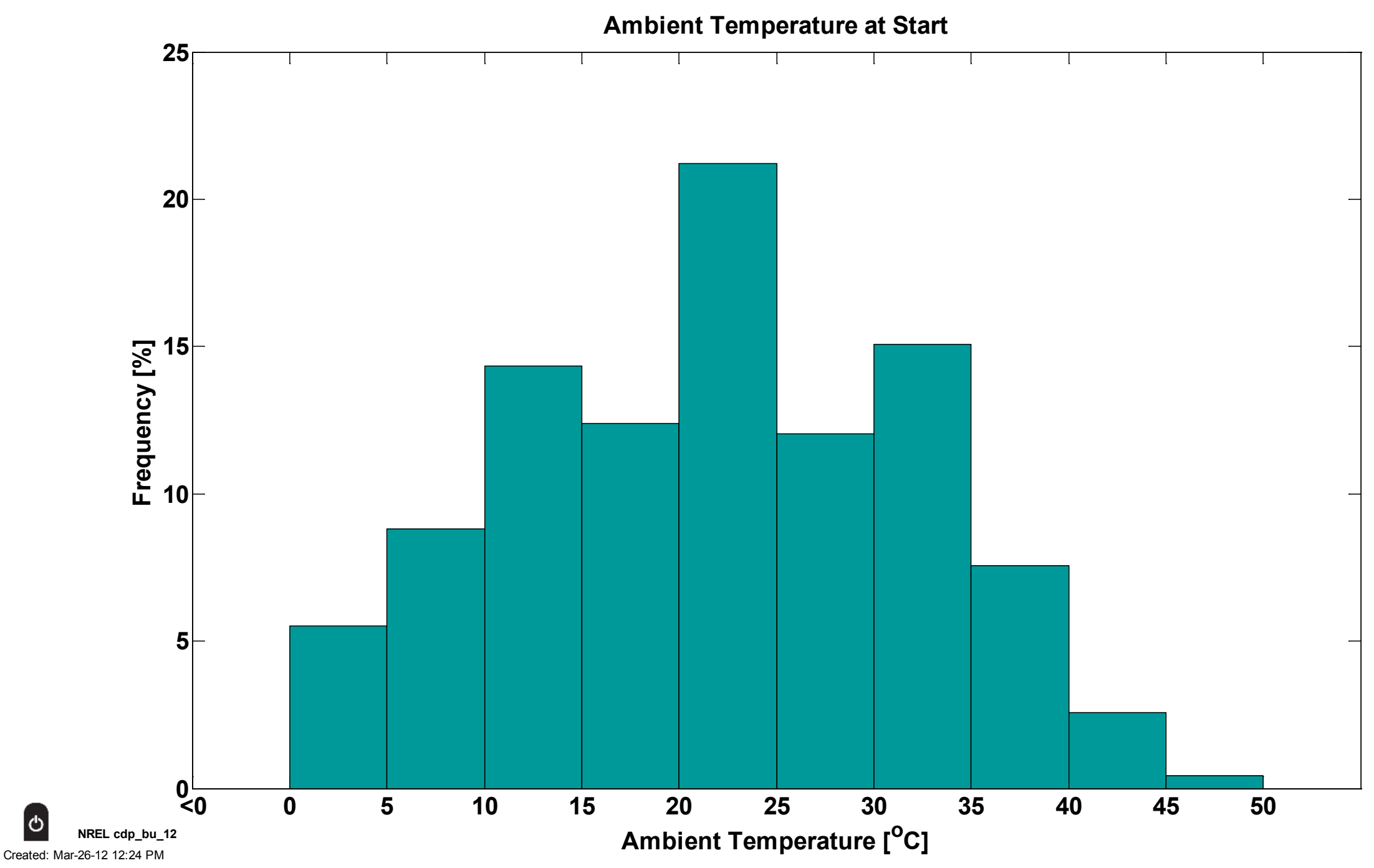




\section{System Operation Time}

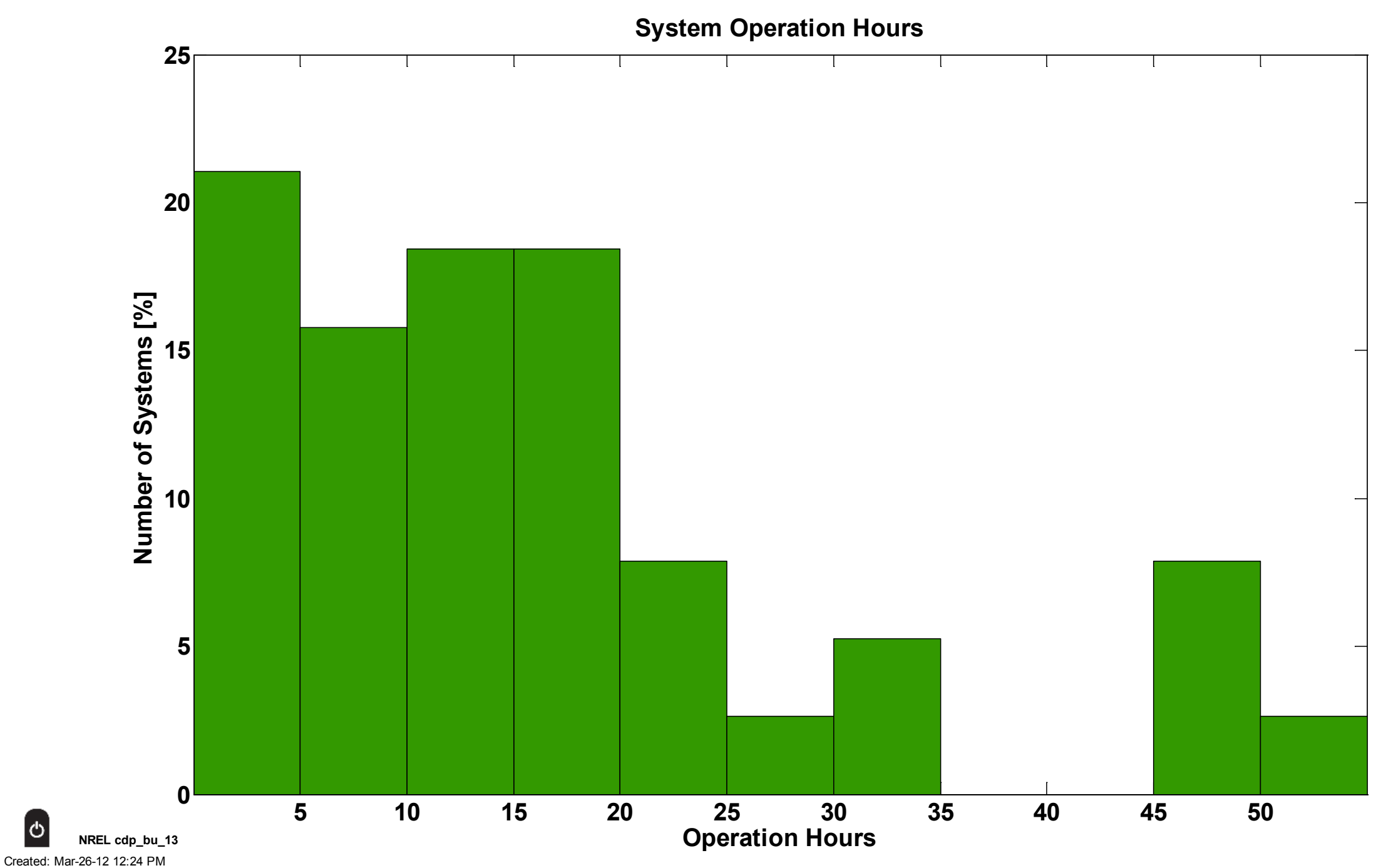

